
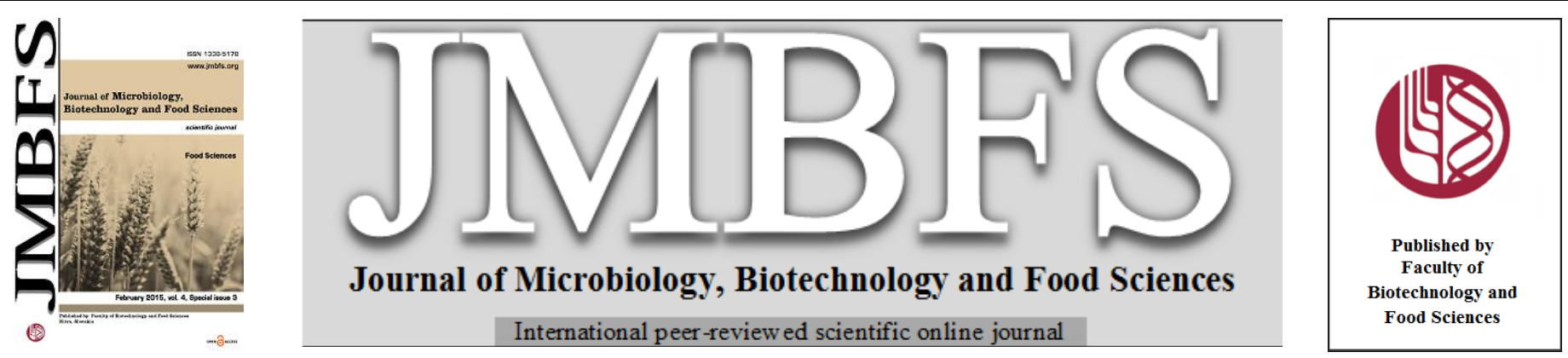

\title{
THE RESEARCH OF TOTAL POLYPHENOLS CONTENT AND THEIR CHANGES IN DIFFERENT VARIETIES OF POTATOES
}

\section{Beáta Volnová*, Janette Musilová, Diana Hrabovská, Judita Bystrická, Petra Kavalcová, Miriama Kopernická}

Address(es): Ing. Beáta Volnová

Slovak University of Agriculture, Faculty of Biotechnology and Food, Department of Chemistry, Trieda A. Hlinku 2, 94976 Nitra, Slovakia, phone number: 036/6414375.

*Corresponding author: bejatkavolnova@pobox.sk

doi: 10.15414/jmbfs.2015.4 special3.181-184

\section{ART ICLE INFO}

Received 27.11.2014

Revised 3. 12. 2014

Accepted 4. 12. 2014

Published 2. 2. 2015

Regular article open $\partial_{\text {AcCESS }}$

\begin{abstract}
Polyphenols are secondary metabolites of plants with antioxidant properties. In this work we research the changes in the content of total polyphenols in fivevarieties of potatoes (Rumelia, Arwen, Megan, Malvína, Erídia). Potatoes were grown at the stage of full maturity from Matejovcenad Hornádom, region of Poprad. Total polyphenols we determined in whole peeled potatoes; in the outside part of peeled potato tubers $(1 \mathrm{~cm})$; in inside part of potato tubers (mean $2 \mathrm{~cm}$ ) and in the whole peel-boiled potatoes. The total polyphenols content was determined by spectrophotometry $(\lambda=765 \mathrm{~nm})$ and it was used lyophilized samples in ethanol extracts. In whole peeled potatoes was the content of total polyphenols in the range from $243.34 \mathrm{mg} \cdot \mathrm{kg}^{-1} \mathrm{DM}$ (cv. Rumelia) to $446.38 \mathrm{mg} \cdot \mathrm{kg}^{-1} \mathrm{DM}$ (cv. Megan), in the out side part of peeled potato tubers was content in the range from $190.45 \mathrm{mg} \cdot \mathrm{kg}^{-1}$ (cv. Rumelia) to $446.84 \mathrm{mg} . \mathrm{kg}^{-1} \mathrm{DM}$ (cv. Malvína) and in inside part of potato tubers from $245.51 \mathrm{mg} \cdot \mathrm{kg}^{-1}$ to $446.26 \mathrm{mg} \cdot \mathrm{kg}^{-1} \mathrm{DM}$ (Arwen < Rumelia $<$ Megan $<$ Erídia $<$ Malvína). In the whole peel-boiled potatoes was the lowest content of total polyphenols in variety Rumelia $\left(252.5 \mathrm{mg} . \mathrm{kg}^{-1} \mathrm{DM}\right)$ and the highest content in variety Megan (440.54 mg. $\mathrm{kg}^{-1} \mathrm{DM}$ ). Results were statistically evaluated by the Analysis of Variance (ANOVA - Multiple Range Tests, Method: 95.0 percent LSD) using statistical soft ware ST AT GRAPHICS (Centurion XVI.I, USA) and the regression and correlation analysis (Microsoft Excel) was used.
\end{abstract}

Keywords: Potatoes, total polyphenols, variety, locality

\section{INTRODUCTION}

Potato (Solanum tuberosum L.) is the fifth of most important crop worldwide after sugar cane, maize, wheat and rice with a production of $x>329$ million tons in 2009. Potato is recognized as a source of carbohydrates, high-quality proteins, vitamin C, vitamin B6, vitamin B3 and minerals such as potassium, phosphorous and magnesium (Andre $\boldsymbol{e t}$ al.,2007). Besides these basic nutrients, some pot ato varieties contain polyphenolic compounds. Polyphenols are secondary plant metabolites and are important determinants of the sensory and nutritional qualities of fruits, vegetables and other plants. Even though their high antioxidant capacity, polyphenols may have possible beneficial implications on human health, such as in the treatment and prevention of cancer, cardiovascular disease and other pathologies, and should be an important research area in recent years (Ignat et al., 2011). Camire et al. (2009) declare that polyphenols also contain important amounts of polyphenols, a class of secondary plant metabolites although fruits, vegetables, cereals, chocolate and drinks (red wine, coffee and fruit juices) are the main sources of polyphenols in our diet (Manach et al., 2004; Scalbert et al., 2005). The polyphenol content of potatoes is worth exploring sincepotato consumption is highly compared to other vegetables in Europe. Brat et al. (2006) investigated the total phenolic content of 29 vegetables consumed in France and their contribution to the total phenolic uptake based on per capita consumption data. Polyphenols are plant secondary metabolites. They have diverse structure, molecular mass as well as varied physical, biological and chemical properties. They occur in plant parts including flowers, fruit, seeds, leaves, roots, bark and its wooden parts. Polyphenolic compounds in plants participate not only in their reproduction and growth but also affect the sensory qualities of plant-derived processed foods such as taste, colour or texture (Perla et al., 2012). Polyphenolic exceed biological activity in the human body, among others they take active part in the removal of free radicals, metal ion chelatation as well as affect enzyme activity and protein availability. Even though their health beneficial properties, polyphenolic compounds prevent, among others, coronary heart disease, cancer, inflammatory diseases (Lachman et al., 2013).

\section{MATERIAL AND METHODS}

For analyses we used the samples of five different potato varieties: very early variety - Erídia; early varieties - Malvína, Rumelia and middle early varieties Megan and Arwen. Analysis of potatoes: From potatoes we made an extract. Total polyphenols (TP) were determined by the method of Lachman et al. (2003) and expressed in mg eq. gallic acid per $\mathrm{kg}$ fresh mater. Gallic acid is usually used as a standard unit for phenolics content determination because a wide spectrum of phenolic compounds. The TP content was estimated using Folin-Ciocalteau reagent. The Folin-Ciocalteau phenol reagent was added to a volumetric flask containing an aliquot of extract. The content was mixed and a sodium carbonate solution $(20 \%)$ was added after $3 \mathrm{~min}$. The volume was adjusted to $50 \mathrm{ml}$ by adding of distilled water. After 2 hours, the samples were centrifuged for $10 \mathrm{~min}$. and the absorbance was measured at $765 \mathrm{~nm}$ of wave length against blank. The concentration of polyphenols was calculated from a st andard curve plotted with known concentration of gallic acid. Samples of the plant material, we collected at the stage of full maturity from Matejovce, region of Poprad. Soil from this area have been weakly alkaline, with central supply humus, very low content of phosphorus, high content of magnesium and good potassium content (Bielek, 1996) (Tab.1)

Table 1 Characteristics of the soil and nutrient content $\left(\mathrm{mg}^{-\mathrm{kg}^{-1}}\right)$

\begin{tabular}{|c|c|c|c|c|c|c|c|}
\hline \multirow{2}{*}{ Point of delivery } & \multirow{2}{*}{$\mathrm{pH}(\mathrm{KCl})$} & $\mathrm{C}_{\mathrm{ox}}$ & mold & \multicolumn{4}{|c|}{ Nutrient content } \\
\hline & & $(\%)$ & & $\mathrm{P}$ & $\mathrm{K}$ & $\mathrm{Ca}$ & $\mathrm{Mg}$ \\
\hline Matejovce & 5.75 & 1.56 & 2.69 & 36.27 & 191.03 & 2689.50 & 168.0 \\
\hline
\end{tabular}

In soil samples we set the agrochemical characteristics of the soil (the soil exchange reaction $\mathrm{pH} / \mathrm{KCl}, \mathrm{Cox}(\%)$ - oxidimetry $\%$ of the translation method as
Ť urin and \% mold - of Cox) and nutrient contents. Nutrient contents ( $\mathrm{P}, \mathrm{K}, \mathrm{Ca}$, $\mathrm{Mg}$ ) we set by Mehlich method (Mehlich II), analytical method for the 
determination of output was AAS (AAS Varian AA Spectr DUO 240FS/240Z/UltrAA).

\section{RESULTS AND DISCUSSION}

Potato tuber is growing for its rhizone tubers, which is known as potatoes. Potatoes filled in human nutrition mainly for volume function, than eating function and protective function. Potatoes are an important food, industrial raw materials, feed and a major agricultural crops with high yield potentially useful biomass (Frančáková, 2001). Potato tubers in human nutrition represent a significant source of antioxidants. The main antioxidants in potatoes are polyphenolic compounds (Lachman et al., 2008). Polyphenols are accumulated in the healthy tissue which is fitting to potato tissue as reaction on pathogen attack, while also acknowledging the synergies between phenolic compounds with similar structure and protect against some (but not all) phytopathogens (Krištůfek et al., 2001). In our work, we watched changes total polyphenols content in different parts of potatoes. We analysed inside part of peeled potatoes, outside part of peeled potatoes, whole peel-boiled potato and whole peeled potatoes. Determined values in variety Erídia were: inside part of peeled potatoes $402.32 \mathrm{mg} . \mathrm{kg}^{-1} \mathrm{DM}$ to $409.60 \mathrm{mg} \cdot \mathrm{kg}^{-1} \mathrm{DM}$; in outside part of peeled potatoes $383.64 \mathrm{mg} \cdot \mathrm{kg}^{-1}$ DM to $430.80 \mathrm{mg} \cdot \mathrm{kg}^{-1} \mathrm{DM}$; in whole peel-boiled potatoes 405.00 mg.kg-1 DM to $426.20 \mathrm{mg} \cdot \mathrm{kg}^{-1} \mathrm{DM}$ and in whole peeled potatoes from 420.52 mg.k ${ }^{-1}$ DM to 436.28 mg.kg ${ }^{-1}$ DM. Determined values in variety Arwen were: inside part of peeled potatoes $215.24 \mathrm{mg} \cdot \mathrm{kg}^{-1} \mathrm{DM}$ to $278.60 \mathrm{mg} \cdot \mathrm{kg}^{-1} \mathrm{DM}$; in out side part of peeled potatoes from $324.40 \mathrm{mg} \cdot \mathrm{kg}^{-1} \mathrm{DM}$ to $374.60 \mathrm{mg} \cdot \mathrm{kg}^{-1} \mathrm{DM}$ in whole peel-boiled potatoes $258.20 \mathrm{mg} \cdot \mathrm{kg}^{-1} \mathrm{DM}$ to $265.52 \mathrm{mg} \cdot \mathrm{kg}^{-1} \mathrm{DM}$ and in whole peeled potatoes $247.32 \mathrm{mg} . \mathrm{kg}^{-1} \mathrm{DM}$ to $309.00 \mathrm{mg} . \mathrm{kg}^{-1} \mathrm{DM}$. In variety Rumelia total polyphenolcontent were: inside part of peeled potatoes 238.64 mg. $\mathrm{kg}^{-1} \mathrm{DM}$ to $339.20 \mathrm{mg} \cdot \mathrm{kg}^{-1} \mathrm{DM}$; in outside part of peeled potatoes from $161.76 \mathrm{mg} \cdot \mathrm{kg}^{-1} \mathrm{DM}$ to $221.72 \mathrm{mg} . \mathrm{kg}^{-1} \mathrm{DM}$; in whole peel-boiled potatoes from $219.60 \mathrm{mg} \cdot \mathrm{kg}^{-1}$ DM to $277.16 \mathrm{mg} \cdot \mathrm{kg}^{-1} \mathrm{DM}$ and in whole peeled potatoes from $229.20 \mathrm{mg} \cdot \mathrm{kg}^{-1}$ DM to $259.12 \mathrm{mg} . \mathrm{kg}^{-1}$ DM. In variety Megan total polyphenol content was: inside part of peeled potatoes from $336.48 \mathrm{mg} . \mathrm{kg}^{-1} \mathrm{DM}$ to 412.40 mg.kg ${ }^{-1} \mathrm{DM}$; in outside part of peeled potatoes from $375.16 \mathrm{mg} \cdot \mathrm{kg}^{-1} \mathrm{DM}$ to $439.24 \mathrm{mg} \cdot \mathrm{kg}^{-1} \mathrm{DM}$; in whole peel-boiled potatoes from $422.12 \mathrm{mg} \cdot \mathrm{kg}^{-1} \mathrm{DM}$ to $464.76 \mathrm{mg} \cdot \mathrm{kg}^{-1} \mathrm{DM}$ and in whole peeled potatoes from $421.16 \mathrm{mg} \cdot \mathrm{kg}^{-1} \mathrm{DM}$ to $471.96 \mathrm{mg} \cdot \mathrm{kg}^{-1} \mathrm{DM}$ and in variety Malvína total polyphenols content was: inside part of peeled potatoes from $428.36 \mathrm{mg} \cdot \mathrm{kg}^{-1} \mathrm{DM}$ to $465.00 \mathrm{mg} \cdot \mathrm{kg}^{-1} \mathrm{DM}$; in out side part of peeled potatoes from $422.24 \mathrm{mg} \cdot \mathrm{kg}^{-1} \mathrm{DM}$ to $472.56 \mathrm{mg} \cdot \mathrm{kg}^{-1} \mathrm{DM}$; in whole peel-boiled potatoes from $363.24 \mathrm{mg} \cdot \mathrm{kg}^{-1} \mathrm{DM}$ to $434.00 \mathrm{mg} \cdot \mathrm{kg}^{-1} \mathrm{DM}$ and in whole peeled potatoes from $430.80 \mathrm{mg} \cdot \mathrm{kg}^{-1} \mathrm{DM}$ do $447.80 \mathrm{mg} \cdot \mathrm{kg}^{-1} \mathrm{DM}$

Table 2 Total polyphenols content

\begin{tabular}{|c|c|c|c|c|}
\hline \multicolumn{5}{|c|}{ Total polyphenols content $\left(\mathrm{mg} \cdot \mathrm{kg}^{-1}\right)$} \\
\hline variety & $\begin{array}{l}\text { inside part of peeled } \\
\text { potatoes }\end{array}$ & $\begin{array}{l}\text { outside part of peeled } \\
\text { potatoes }\end{array}$ & $\begin{array}{ll}\text { whole } & \text { peel-boiled } \\
\text { potatoes } & \end{array}$ & whole peeled potatoes \\
\hline Erídia & $402.32 \pm 3.27$ & $383.64 \pm 20.73$ & $415.88 \pm 8.67$ & $420.52 \pm 7.76$ \\
\hline Arwen & $215.24 \pm 28.70$ & $324.40 \pm 25.67$ & $258.20 \pm 4.40$ & $247.32 \pm 30.74$ \\
\hline Rumelia & $238.64 \pm 8.88$ & $161.76 \pm 31.41$ & $219.60 \pm 27.87$ & $229.20 \pm 13.86$ \\
\hline Megan & $336.48 \pm 31.17$ & $375.16 \pm 27.25$ & $422.12 \pm 18.14$ & $421.16 \pm 23.19$ \\
\hline Malvína & $428.36 \pm 15.95$ & $422.24 \pm 23.74$ & $363.24 \pm 33.66$ & $408.32 \pm 16.22$ \\
\hline
\end{tabular}

Table 3 ANOVA T able for inside part of peeled potatoes by variety

\begin{tabular}{llllll}
\hline Source & Sum of Squares & Df & Mean Square & F-Ratio & P-Value \\
\hline Between groups & 110430.0 & 4 & 27607.4 & 31.02 & 0.0000 \\
\hline Within groups & 13350.3 & 15 & 890.019 & & \\
\hline Total (Corr.) & 123780. & 19 & & & \\
\hline
\end{tabular}

Table 4 Multiple Range Tests for inside part of peeled potatoes by variety, Method: 95.0 percent LSD

\begin{tabular}{llll}
\hline variety & Count & Mean & Homogeneous Groups \\
\hline Arwen & 4 & 245.51 & $\mathrm{X}$ \\
\hline Rumelia & 4 & 290.93 & $\mathrm{X}$ \\
\hline Megan & 4 & 377.27 & $\mathrm{X}$ \\
\hline Erídia & 4 & 406.99 & $\mathrm{XX}$ \\
\hline Malvína & 4 & 446.26 & $\mathrm{X}$ \\
\hline
\end{tabular}

Statistically significant differences in the content of total polyphenols in inside part of peeled potatoes are between varieties Arwen - Rumelia, Megan, Erídia, Malvína; Rumelia - Arwen, Megan, Erídia, Malvína; Megan - Arwen, Rumelia,
Malvína; Erídia - Arwen, Rumelia, Malvína and between varieties Malvína Arwen, Rumelia, Megan and Erídia.

Table 5 ANOVA Table for outside part of peeled potatoes by variety

\begin{tabular}{llllll}
\hline Source & Sum of Squares & Df & Mean Square & F-Ratio & P-Value \\
\hline Between groups & 164560. & 4 & 41139.9 & 60.83 & 0.0000 \\
\hline Within groups & 10144.0 & 15 & 676.27 & & \\
\hline Total (Corr.) & 174704. & 19 & & & \\
\hline
\end{tabular}

Table 6 Multiple Range Tests for outside part of peeled potatoes by variety, Method: 95.0 percent LSD

\begin{tabular}{llll}
\hline variety & Count & Mean & Homogeneous Groups \\
\hline Rumelia & 4 & 190.45 & $\mathrm{X}$ \\
\hline Arwen & 4 & 351.72 & $\mathrm{X}$ \\
\hline Erídia & 4 & 403.6 & $\mathrm{X}$ \\
\hline Megan & 4 & 413.76 & $\mathrm{XX}$ \\
\hline Malvina & 4 & 446.84 & $\mathrm{X}$ \\
\hline
\end{tabular}

Statistically significant differences in the content of total polyphenols in out side part of peeled potatoes are between varieties Rumelia - Arwen, Erídia, Megan, Malvína; between Arwen - Rumelia, Erídia, Megan, Malvína; Erídia - Rumelia,
Arwen, Malvína; Megan - Rumelia, Arwen, Malvina and between varieties Malvína-Rumelia, Arwen, Megan and Erídia.

Table 7 ANOVA Table for whole peel-boiled potato by variety

\begin{tabular}{llllll}
\hline Source & Sum of Squares & Df & Mean Square & F-Ratio & P-Value \\
\hline Between groups & 124750.0 & 4 & 31187.4 & 66.80 & 0.0000 \\
\hline Within groups & 7003.2 & 15 & 466.88 & & \\
\hline Total (Corr.) & 131753.0 & 19 & & & \\
\hline
\end{tabular}


Table 8 Multiple Range T ests for whole peel-boiled potato by variety, Method: 95.0 percent LSD

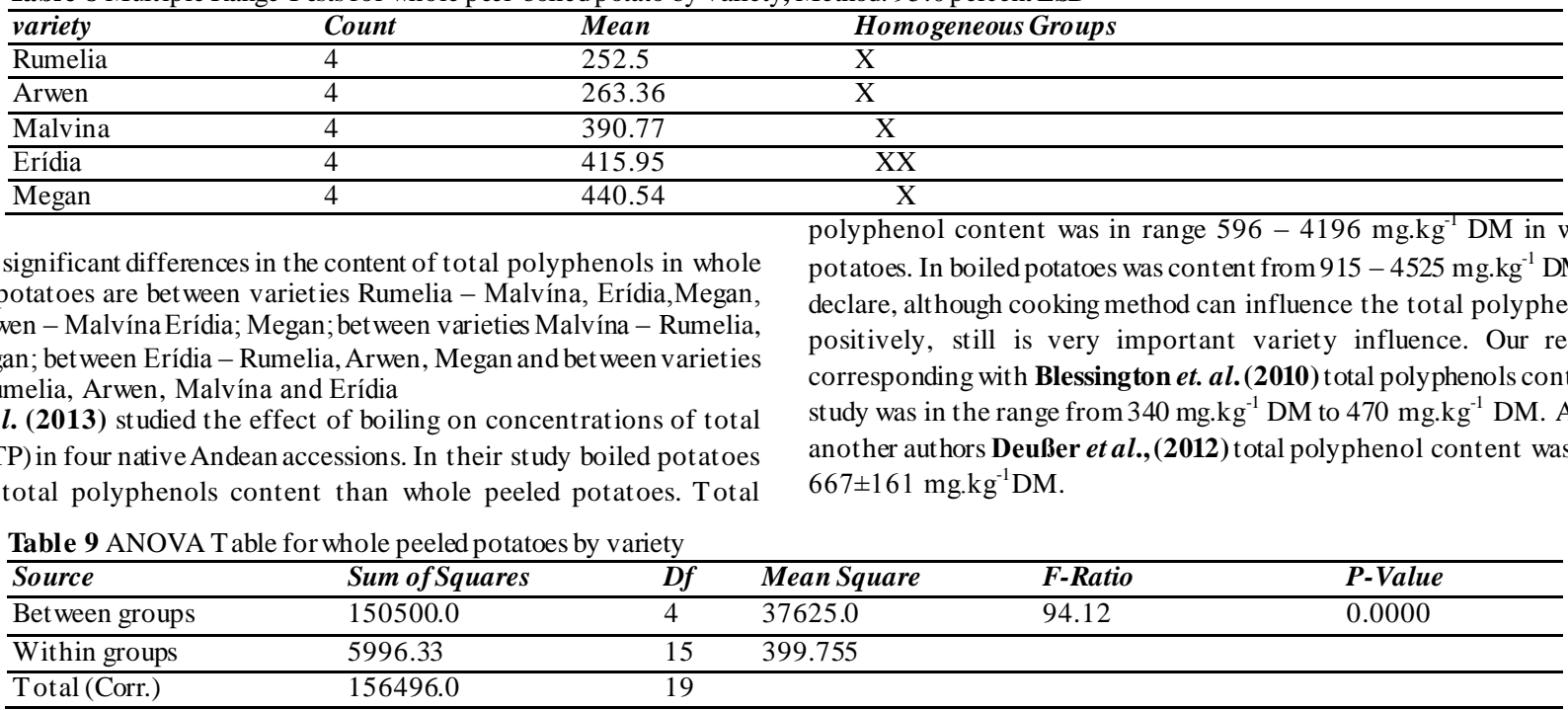

Statistically significant differences in the content of total polyphenols in whole peel-boiled potatoes are between varieties Rumelia - Malvína, Erídia,Megan, between Arwen - MalvínaErídia; Megan; between varieties Malvína - Rumelia, Arwen, Megan; between Erídia - Rumelia, Arwen, Megan and between varietie Megan - Rumelia, Arwen, Malvína and Erídia

Burgos et al. (2013) studied the effect of boiling on concentrations of tota phenolics (TP) in four native Andean accessions. In their study boiled potatoes had higher total polyphenols content than whole peeled potatoes. Total

polyphenol content was in range $596-4196 \mathrm{mg} \mathrm{kg}^{-1} \mathrm{DM}$ in whole peeled positively, still is very important variety influence. Our results are in another authors Deußer et al.,(2012) total polyphenol content was in range of

Table 10 Multiple Range Tests for whole peeled potatoes by variety, Method: 95.0 percent LSD

\begin{tabular}{llll}
\hline variety & Count & Mean & Homogeneous Groups \\
\hline Rumelia & 4 & 243.34 & $\mathrm{X}$ \\
\hline Arwen & 4 & 274.72 & $\mathrm{X}$ \\
\hline Erídia & 4 & 427.25 & $\mathrm{X}$ \\
\hline Malvina & 4 & 429.64 & $\mathrm{X}$ \\
\hline Megan & 4 & 446.38 & $\mathrm{X}$ \\
\hline
\end{tabular}

Statistically significant differences in the content of total polyphenols in whole peeled potatoes are between varieties Rumelia - Arwen, Erídia, Malvína, Megan; between Arwen - Rumelia, Erídia, Malvína Megan; between varieties Erídia Rumelia, Arwen; between Malvína and Rumelia, Arwen and between varieties Megan - Rumelia and Arwen.

Between the content of total polyphenols in whole peeled potatoes and in whole peel-boiled potatoes in variety:

Arwen there is a strong positive statistically significant correlation $(\mathrm{R}=$ 0.961 ; P-value $(0.038)<0.05)$. Variability of total polyphenols content in whole peel-boiled potatoes and whole peeled potatoes of selected regression line explained $92.5 \%\left(\mathrm{R}^{2}=0.925\right)$,

Rumelia there is a strong positive statistically significant correlation $(\mathrm{R}=$ 0.969 ; P-value $(0.030)<0.05)$. Variability of total polyphenols content in whole peel-boiled potatoes and whole peeled potatoes of selected regression line explained $94.0 \%\left(\mathrm{R}^{2}=0.940\right)$,

Megan is positive statistically significant correlation $(\mathrm{R}=0.954$; $\mathrm{P}$-value $(0.045)<0.05)$. Variability of total polyphenols content in whole peel-boiled potatoes and whole peeled potatoes of selected regression line explained on $91.1 \%\left(\mathrm{R}^{2}=0.911\right)$,

Malvína there is not statistically significant correlation $(\mathrm{R}=0.831$; $\mathrm{P}$-value $(0.16)>0.05)$. Variability of total polyphenols content in whole peel-boiled potatoes and whole peeled potatoes of selected regression line explained on $69.1 \%\left(\mathrm{R}^{2}=0.691\right)$,

Erídia there is not statistically significant correlation $(\mathrm{R}=0.904$; $\mathrm{P}$-value $(0.095)>0.05)$. Variability of total polyphenols content in whole peel-boiled potatoes and whole peeled potatoes of selected regression line explained on $81.7 \%\left(\mathrm{R}^{2}=0.817\right)$.

\section{CONCLUSION}

In our work we deal with the research of changes to the total polyphenols content in different varieties of potatoes. Total polyphenolic content we determined by spectrophotometry in inside part of peeled potatoes; outside part of peeled potatoes; in whole peel-boiled potatoes and in whole peeled potatoes. The highest total polyphenols content in inside part of peeled potatoes was in variety Malvína $465.00 \mathrm{mg} \cdot \mathrm{kg}^{-1} \mathrm{DM}$ and the lowest content in variety Arwen $215.24 \mathrm{mg} \cdot \mathrm{kg}^{-1} \mathrm{DM}$. In out side part of peeled potatoes was TPC in variety Rumelia $161.76 \mathrm{mg} \cdot \mathrm{kg}^{-1}$ $\mathrm{DM}$ and the highest content in variety Malvína $472.56 \mathrm{mg} \cdot \mathrm{kg}^{-1} \mathrm{DM}$. In whole peel-boiled potatoes the total polyphenols content was in variety Rumelia 219.60 mg.kg ${ }^{-1} \mathrm{DM}$ and the highest content was in variety Megan $464.76 \mathrm{mg} . \mathrm{kg}^{-1} \mathrm{DM}$. In whole peeled potatoes was the highest content in variety Megan $471.96 \mathrm{mg} . \mathrm{kg}$ ${ }^{1} \mathrm{DM}$ and lowest content in variety Rumelia $229.20 \mathrm{mg} \cdot \mathrm{kg}^{-1} \mathrm{DM}$.

The effect on variety in the total polyphenols content was in all cases highest statistically significant between content of polyphenols. There confirmed the weak variety dependence in inside part of peeled potatoes and in out side part of peeled potatoes.

Acknowledgments: Article was developed with the financial support by grant VEGA 1/0456/12.

\section{REFERENCES}

ANDRE, C.M., GHISLAIN M., BERTIN P., OUFIR M., HERRERA M.D., HOFFMANN L., HAUSMAN J.F., LARONDELLE Y., EVERS D. 2007. Andean potato cultivars (Solanum tuberosum L.) as a source of antioxidant and mineral micronut rients. Journal of A gricultural and Food Chemistry, 55, 366-378 http://dx.doi.org/10.1021/jf062740i

BIELEK, P. 1996. Ochrana pôdy. Kódex správnej pol’nohospodárskej praxe. VÚPÚ Bratislava, 1996, ISBN 80-85361-21-3. http://dx.doi.org/10.1103/physrevb.54.4000

BLESSINGTON, T., NZARAMBA, M.N., SCHEURING, D., HALE, A.L., REDDIVARI, L., MILLER, JR J.C. 2010. Cooking methods and storage treatments of potato: effects on carotenoids, antioxidant activity, and phenolics. American Journal of Potato Research, 87 , 479-491 http://dx.doi.org/10.1007/s12230-010-9150-7

BRAT P., GEORGE S., BELLAMY A., DU C.L., SCALBERT A., MENNEN L., et al. 2006 Daily polyphenol intake in France from fruit and vegetables. Journal of Nutrition, 136, 2368-2373 http://dx.doi.org/10.3109/09637486.2013.816938

BURGOS, G., AMOROS, W., MUÑOA, L., SOSA, P., CAYHUALlA, E., SANCHEZ, C., DÍAZ, C., BONIERBALE, M. 2013.Total phenolic, total anthocy anin and phenolic acid concentrations and anti oxidant activity of purplefleshed potatoes as affected by boiling. Journal of Food Composition and Analysis, 30, 6-12. http://dx.doi.org/10.1016/j.jfca.2012.12.001 CAMIRE M.E., KUBOW S., DONNELLY D.J. 2009. Potatoes and human health. Critical Reviews in Food Science and Nutrition, 49, 823-840 http://dx.doi.org/10.1080/10408390802145724DEUßER, H., GUIGNARD, C., HOFFMANN, L., EVERS, D., 2012. Polyphenol and glycoalkaloid contents in potato cultivars grown in Luxembourg. Food Chemistry, 135, 2814-2824 Other IDs: S0308814612011405 http://dx.doi.org/10.1016/j.foodchem.2012.07.028 FRANČÁKOVÁ, H. 2001. Zemiaky - suroviny a potravina. In Hodnotenie surovín a potravín rastlinného pôvodu. Nitra: SPU, 156, ISBN 80-7137-886-0 IGNAT, I ht tp://www.sciencedirect.com/science/article/pii/S0308814610016353 - cor1, VOLF I. , POPA V. 2011. A critical review of methods for characterisation of polyphenolic compounds in fruits and vegetables. Food Chemistry, 15, 1821-1835 http://dx.doi.org/10.1016/j.foodchem.2010.12.026 KRIŠT ŮFEK, V., PELIKÁNOVÁ, L., DIVIŠ, J. 2001. Obsah polyfenolických látek ve slupce hlíz brambor ve vztahu k výskytu strupovitosti. In Bramborářství, IX, 5, 4-7. ISSN 1211-2429.

LACHMAN, J.

http://www.sciencedirect.com/science/article/pii/S0304423808001088 
cor1mailto:lachman@af.czu.czK. ORSÁK, M PIVEC, V. DVOŘÁK, P. 2008 The influence of flesh colour and growing locality on polyphenolic content and antioxidant activity in potatoes. Scientia Horticulturae 117, 109-114 http://dx.doi.org/10.1016/j. scienta.2008.03.030

LACHMAN, K. HAMOUZ, J. MUSILOVÁ, K. HEJTMÁNKOVÁ, Z

KOTÍKOVÁ, K. PAZDERU, et al.2013 Effect of peeling and three cooking methods on the content of selected phytochemicals in potato tubers with various colour of flesh. Food Chemistry, 138, 1189-1197 http://dx.doi.org/10.1016/j.foodchem.2012.11.114

MANACH, Y. L 2004 The impact of postoperative discontinuation or continuation of chronic statin therapy on cardiac outcome after major vascular surgery. Journal of Vascular Surgery, 46, 5, 1081 http://dx.doi.org/10.1016/j.jvs.2007.09.025

PERLA V, HOLM D.G., JAYANT Y S.S 2012 Effect of cooking methods on polyphenols, pigments and antioxidant activity in potato tubers. Food Science and Technology, 45, 161-171 http://dx.doi.org/10.1016/j.lwt.2011.08.005 SCALBERT A., JOHNSON I.T., SALTMARSH M. 2005 Polyphenols: Antioxidants and beyond American Journal of Clinical Nutrition, 81, 215S-217S http://dx.doi.org/10.1080/1040869059096 